\title{
Challenges of the Cultural Policies as a Sustainable Development Engine: Example of a Good Policy / City of Pancevo
}

\author{
Bojana Subasic ${ }^{1}$ \\ Bogdana Opacic ${ }^{2}$
}

\begin{abstract}
Reforming cultural policy in Serbia comes into a focus after year 2000. With delegating jurisdiction on the local cultural systems, because one of the ideas is that local government and experts can recognize needs, potential and capacities for local development more clearly and comprehensively. This work deals with the challenges of cultural policy as initiators of sustainable development, where the City of Pancevo has been selected as an example of a good practice. The first part of the text deals with challenges of cultural policy on national level. When it comes to cultural policy development on the Republic level, one can say that participants in culture in Serbia contribute to improving culture every year. However, for more successful cultural policy it is necessary to approach cultural policy challenges in service of sustainable development. Ranking all challenges leads to a conclusion that it is necessary to solve problems such as financing of the institutions, lack of a strategic thinking and insufficient inter-sector, inter-department and international cooperation. The second part of the text is dedicated to the City of Pancevo, as an example of a good practice in cultural policy and sustainable development domain. During 2013. with the support of the IPA fund cross-border cooperation program, the City of Pancevo accomplished Poles of Culture project. Within that project the Center for Study in Cultural Development conducted a research of cultural needs and habits of citizens of Pancevo, cultural institutions and citizen associations within culture. The third part of the text deals with the research results of cultural needs and habits of Pancevo citizens. They represent guidelines for improving the city cultural policy. The fourth part of the text is dedicated to the cultural policy on the local level and recommendations for cultural policy improvement has been given based on the example of the City of Pancevo.
\end{abstract}

Keywords: cultural infrastructure, cultural policy, funding, strategic planning, cooperation JEL Classification: Z1, Z10

\footnotetext{
1 MA of sociology, researcher at the Center for Study in Cultural Development, cultural institution of national significance, Rige od Fere 4, Belgrade 11000, Republic of Serbia, email: bojana.subasic@zaprokul.org.rs

2 MA of archeology, researcher at the Center for Study in Cultural Development, cultural institution of national significance, Rige od Fere 4, Belgrade 11000, Republic of Serbia, email: bogdana@zaprokul.org.rs
} 


\section{Introduction}

Pointing out the meaning of the culture in a general social development becomes more and more visible during 1990s. UNESCO`s Intergovernmental Conference on Cultural Policies for Development (Stockholm, 1998.) stated the importance of cultural policy as one of the main factors of the sustainable development. The idea of the Mexico City Declaration (1982.) has been re-stated, and according to it, cultural policy does not refer only to art and literature but also intertwines all other aspects of society: social policy, education, cultural industry and creative economy. (http://www.wwcd.org/policy/Stockholm.html, accessed on 04.06.2015.)

Along with the competences increase of the local governments all over the world, local cultural policies have been the major topic at the end of the 20th century. The European Council document, made by The European Task Force on Culture and Development, In from the Margins, suggests that the local governments should adopt their own cultural strategies which would include: art, media, cultural inheritance and tourism, and all that should be coordinated with their own programs of economic, social and educational development. (http://zaprokul.org.rs/wp-content/uploads/2015/01/Sabac analiza.pdf, accessed 04.06.2015.)

In the 21st century, cultural contribution to the society progress is not in for debate anymore, but it's considered implicit in sustainable development discussions.

After the year 2000, reforming cultural policy in Serbia has become current again, with the accent on delegating jurisdiction to local cultural systems. Within that context, the idea is, that local authorities and experts can understand needs, potentials and capacities for the local cultural development more precise, clear and comprehensive than the State. The Centre for Study in Cultural Development contribution to that process, in the cooperation with Ministry of Culture and Information of Republic of Serbia, was overall research of local cultural systems and their role in implementing state cultural policy goals. (Лазаревић ed. 2011).

\section{Cultural infrastructure - the key element of the cultural policy}

Republic of Serbia, on its area of around $88.000 \mathrm{~km}^{2}$ has 533 public institutions that are opened for around 7 million inhabitants. And more important than the number is the way how these institutions are distributed. Namely, Serbia consists of 25 administrative counties. Each county has administrative centre and few municipalities that legally refer to this centre. Network of institutions is organized in a way that each urban area has at least one cultural institution. Usually, there are two or three cultural institutions in smaller urban areas, and three to six in bigger regional centres. In this respect, it can be 
said that culture is commonly available in Serbia, not only in a spiritual way, but also physically.

There are 10.000 employees in the institutions, but the number of people involved in culture is much larger. During field activities, around 2.000 civil society organizations were mapped as well as more than 900 cultural events and festivals. Owing to ethnic diversity and 27nations present on the territory of Serbia, the largest number of events (about 20 percent) is related to different cultural traditions, intangible heritage, their customs, dances, songs and gastronomy. When it comes to cultural assets, monuments are great potential for cultural and economic development of Serbia. There are over 2.000 monuments in Serbia, declared as cultural assets, out of which 200 are Cultural Heritage of Exceptional Importance and 5 of them are in UNESCO`s World Heritage Sites list. The largest number of cultural assets are from the antique and medieval period.

Regarding the cultural system organization, in Serbia there is no large private foundations, and cultural system lies mainly on public funding, civil engagement and few private initiatives. Ministry of Culture and Media is a core general state institution that defines state cultural policy. But each city defines its own cultural policy in line with the state goals for cultural development. In terms of legislative framework, Serbia has a few laws in a field of culture. Core law is Law on Culture (Official Gazette of the Republic of Serbia 72/2009) but beside that we have few laws regarding cinematography, library activity, publishing and tangible cultural heritage.

\subsection{Cultural institutions according to the founder and the main funding source}

Cultural network of Serbia is financially decentralized. Only around 5\% of the network is founded and funded by the state. More than $90 \%$ institutions is funded by the local governments as their founders. Also 3.5\% of the network is financed by the Province of Vojvodina, the second level of administration (beside state and local government level).

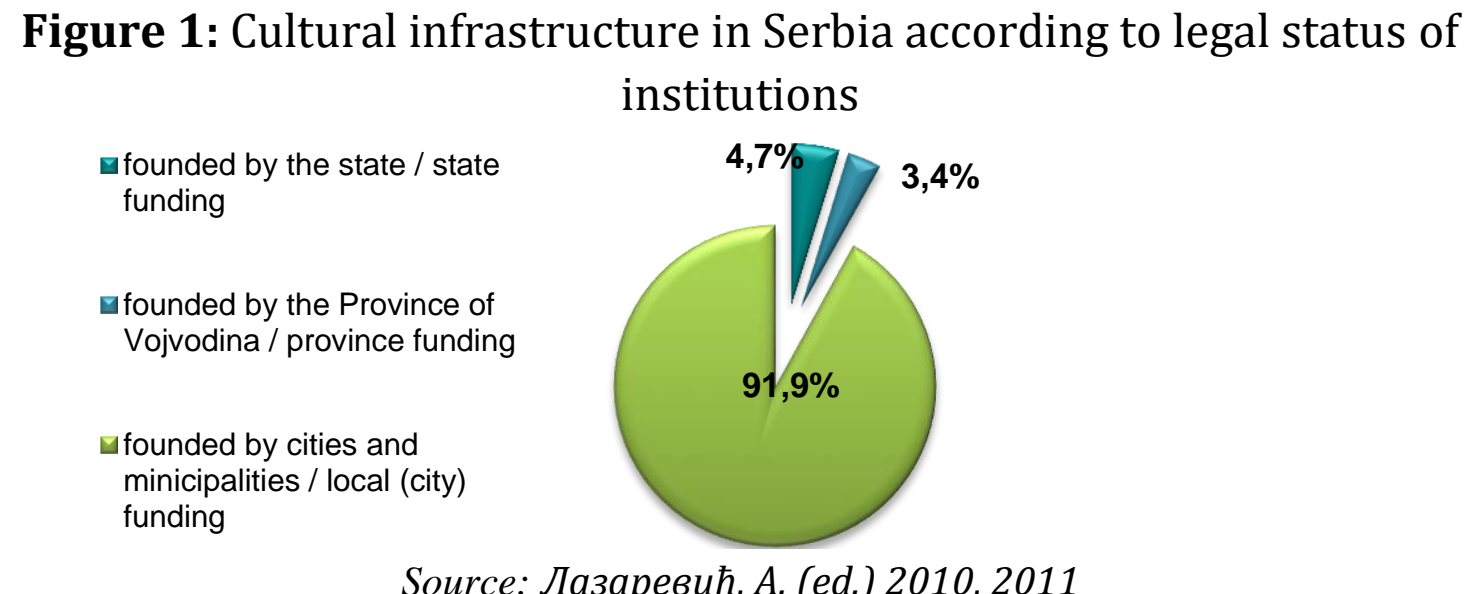

Source: Лазаревић, A. (ed.) 2010, 2011 
Contents and cultural policy are directly achieved through the State cultural institutions, according to government goals. Cultural institutions of the Province support cultural diversity the most, because in this area there are over 25 national minorities. Local institutions and governments develop their own cultural ambience according to the State goals.

\subsection{Cultural institutions according to their domain}

Considering the type of institutions, the third of all institutions are multifunctional cultural centres meant for all kind of cultural programs and events. These institutions are usually located at the city centres and built in the sixties and the seventies of the last century. They literary were and still are centres of cultural life of community. In terms of cultural development, these centers are very valuable places for development of cultural expressions for all interested participants and have great potential for developing cultural industries and economies. And, of course, all other institutions contribute to building cultural identity and to development of culture on local and national level.

All urban areas have a library and, usually a cultural center and museum. Big cities and administrative centers have greatest diversity of institutions and cultural activities.

Figure 2: Cultural institution network in Serbia regarding the type of main activity

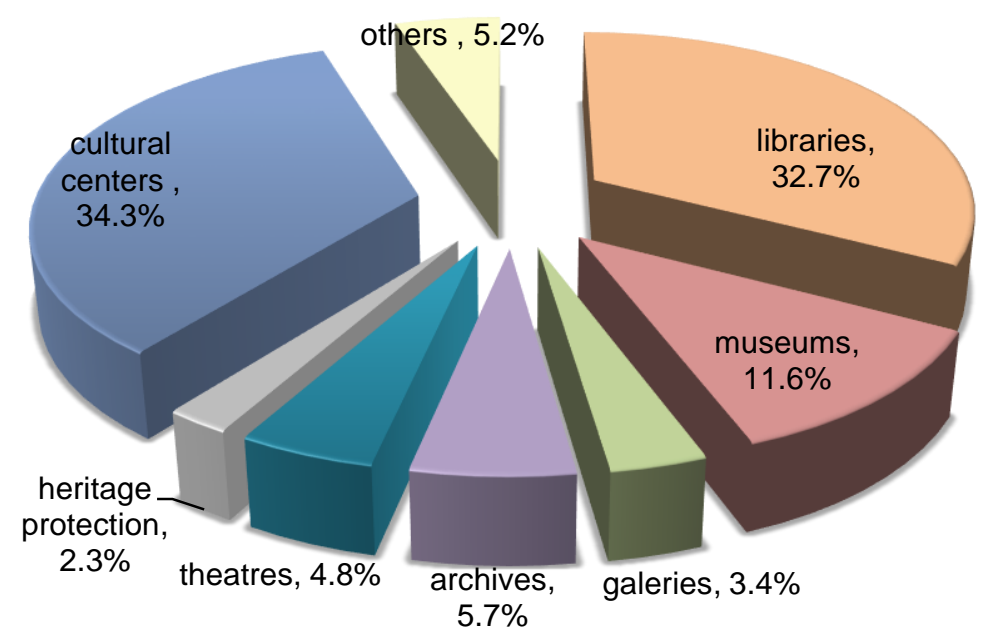

Source: Лазаревић, A. (еd.) 2010, 2011 


\section{Challenges of cultural policy within sustainable development}

As a result of the project four major challenges were recognized in terms of defining cultural policy.

\subsection{Funding}

Funding of cultural institutions raises many problems. Cities and municipalities in Serbia assign about $6 \%$ of their local budget to culture. Local budgets are often small, so in more than half of cities, budget for culture is up to 10 euros per capita, while only major cities in Serbia assign more money. The result of that is small budgets of the institutions, which often are not enough, not only for innovative programs but for common activities too. Therefore, institutions need to find a way to obtain alternative funding resources, such as national and international funds, joint projects and cooperation with civil society organizations. This is a big challenge for public institutions.

Figure 3: Percentage of the cities according to culture budget per capita

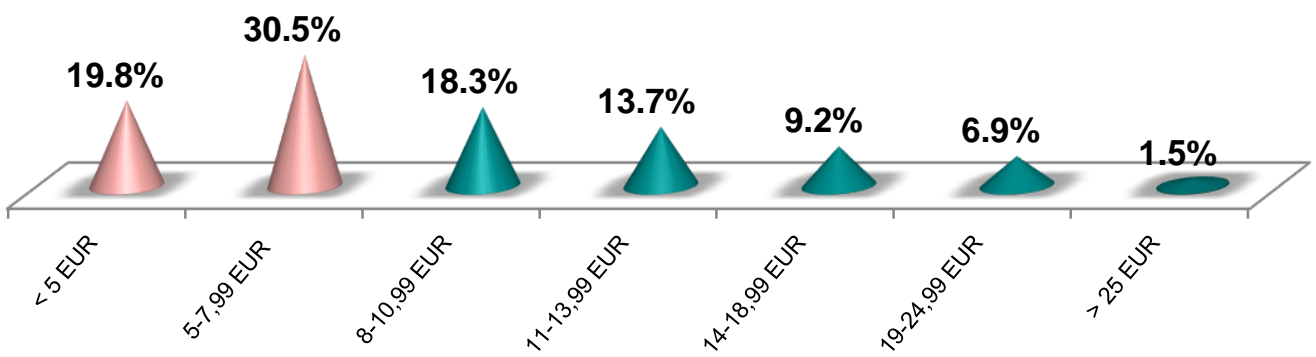

Source: Лазаревић, A. (ed.) 2011: 11

Significant issue is also maintenance of the facilities and lack of funds for urgent or planned interventions. Great number of institutions are placed in buildings that are cultural monuments, which raises costs of maintenance and renovation, because of the special conditions for this kind of work.

\subsection{Employees in a public cultural sector}

Next issue concerns employees in a cultural sector. Main problem is deficiency of additional education and professional trainings. Institutions often do not have plans nor resources for personnel trainings. As a result, many professionals do not have an opportunity to track contemporary flows and changes in a field of culture and can't develop skills in line with demands of modern cultural organization. 
Deficiency of professionals is also a significant issue, especially in smaller urban areas. For example, small towns often don't have high educated librarians, so in libraries we have less educated employees or personnel educated in other fields.

\subsection{Long-term planning and strategic planning}

This is maybe the most important need in culture. Most of institutions have annual plans of activities and do not look any further in the future. This is a big problem when we talk about development of cultural system. Current Law on Culture (Official Gazette of Republic of Serbia 72/2009) states making cultural development strategy in the Republic of Serbia, and accordingly, local governments are in obligation of making their own local cultural development plans (act 7. of Law on Culture says: Local government unit makes cultural development plan to care and satisfy citizens cultural needs within its territory according to the law and Strategy, and funds come from local government unit budget...). The research on cultural policy of the Center for Study in Cultural Development showed that in reality there are more and more cities and municipalities taking an initiative, working on creating local cultural development plan or are already in the implementation process. By now, ten cities created a strategic planning document analysis, draft version or a complete document. However, work on strategic plans often lacks continuity and becomes neglected in the early stages of development. Strategic planning is necessary to define development on cultural institution level too. Lack of long-term plans on all levels directly affects sustainable development of culture.

\subsection{Cooperation practice}

Finally, concern to be dealt with is cooperation practice at all levels, such as:

Institutional cooperation

Cooperation among public cultural participants is a significant issue of cultural development. Institutions mainly cooperate through exchange of programs and equipment. Yet joint ideas are needed, programs and projects that will bring higher quality events.

\section{Interagency cooperation}

Lack of cooperation between culture and other sectors, such as education, tourism and economy in general.

Education and culture: Children and youth in general, beside art classes and school clubs, often do not have cultural programs in their schools. They also lack cultural habits in terms of going to cultural institutions and participate in cultural programs, or in terms of cultural production. The research studies of Center for Study in Cultural Development (Mrđa 2011a, Mrđa 2011b, Лазаревић ed. 2010, Лазаревић ed. 2011, Субашић, Опачић2013) showed that cultural and educational institutions cooperate poorly, and the consequence is low children and youth participation in cultural programs and also in 
poor participation in cultural production (over 80\% of the young ages 15-29 are not involved in cultural activities in their spare time (Mrđa, 2011a:89, Mrđa, 2011b:79)). This situation is not good for the cultural institutions themselves because it doesn't create future audience or artists. Strategy of educational development in Serbia until 2020 also points out the necessity of culture and education networking. (Law on Government - Official Gazette of Republic of Serbia 55/05, 71/05 correction, 101/07, 65/08, 16/11, 68/12 - US and 72/12), and Law on Primary Education (Official Gazette of Republic of Serbia 72/2009, 52/2011 and 55/2013).

Creative culture: In the last few years there have been more and more discussions on economical and developmental aspect of culture, and in that sense, of creative economy and industries.

According to the creative economy experts the creative industries in Serbia follow a mixed economic model, in which both the public and the private sector share responsibility for the development of creative goods and services. Book publishing, the press, the film industry, cinema, advertising, design, fashion etc., are mainly supported by private initiatives and market, while public expenditure and subsidies have been the primary source of supports for museums, archives, heritage, libraries, performing arts (Mikic, 2014:7).

Figure 4: The structure of creative sector actors according to their legal status

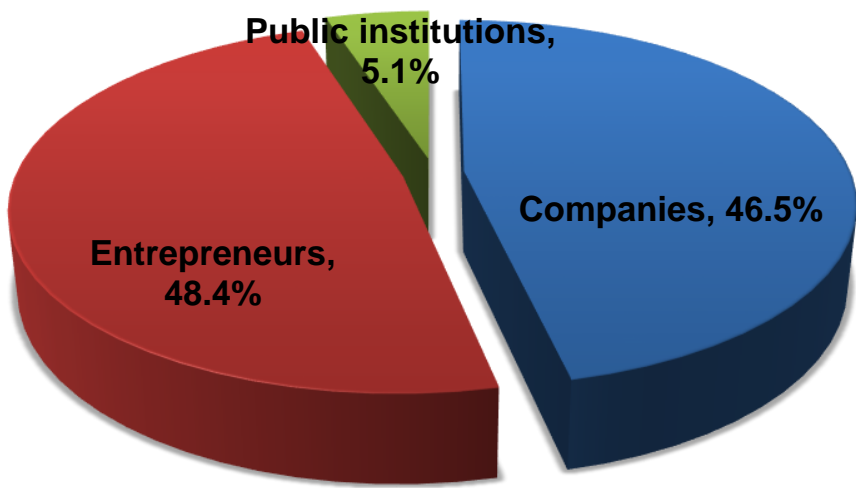

Source: Mikic, 2014:9

Although the public sector participates with only $5.1 \%$ in creative economy, it is important to point out that public cultural institutions can contribute to creative sector development through boosting creative expression within their own programs. That would mean growing creative individuals with different ways of expressing themselves who would participate in creative flows of economy and culture in the future.

One of the largest creative domains for connecting culture and economy is tourism. However, cooperation between cultural institutions and tourism is on a very low level, mainly because of the different understanding of cultural tourism. Cultural 
workers see culture as a value itself, which is a key to a spiritual development of personality and social identities and should not be commercialized. On the other hand, tourist workers, as a part of the economy chain, think that almost every cultural segment can be used for economic growth of the community. Joint education to build skills and connect these two domains can be a significant tool in this segment of sustainable development (Субашић, Миланков, Граф, 2012:142).

Finally, all the research of the Center for Study in Cultural Development about cultural policy and cultural participation (2009- 2014) showed that, in shaping cultural audience, the role of media is not visible enough, and it comes down to reporting, while is necessary to strengthen their promotional and educational aspect.

Public-private-civil partnerships

During the research and interaction with numerous participants of the civil sector it became clear that partnerships in this domain are necessary as means of cultural development. The results show that cooperation between civil and public partners in culture comes down to using space and equipment, but not creating mutual programs, projects and participation in international competitions. That kind of situation has a negative effect to the stability in the civil organizations work, and to possibilities and skills development for alternative financing of public institutions (aside of budget funds).

Motivational system development in including private subjects in cultural activities would be a significant contribution to cultural and general development of society. Sponsorships and donations are rare when it comes to culture. Because of that, systematic measure aimed at development of cooperative responsibility with benefits to economic subjects is of the key importance.

International cooperation

Serbia has a great opportunities for international, cross-border and regional cultural cooperation, exchange of programs and ideas. On this territory there are at least four neighbour countries with similar language and/or historical and cultural context, especially suitable for cross-border/international activities. Yet for the past decade, this cooperation has been more and more visible among civil society organizations, but still has to be developed among different public institutions.

\section{Pancevo - Cultural practice and policy}

Pancevo is an administrative center of the South Banat District in Serbia. It is located 12 $\mathrm{km}$ North-East of the capital city, and it lies on two rivers: the river Tamis and the Danube river, near Romanian border. Pancevo is multi ethnic community with 23 different nationalities living together. That kind of ambience and location creates a possibility to form a multidimensional cultural policy focusing on cooperation, heritage and creative potentials. 
A part of everyday routine of the local government is international cooperation. During the 2013. With the support of the IPA fund for across border cooperation, a project Poles of Culture was being accomplished. Within that project a survey of cultural needs and habits of Pancevo citizens, cultural institutions and citizen associations in culture, was done (Мрђа, Субашић, Опачић, 2014). The results of the research showing cultural sector organization on the local level, can significantly contribute to sustainability aspect development.

\subsection{Dimension of success - the City of Pancevo}

Pancevo is the first city in Serbia to define and accomplish strategic plan in culture. This document was made for a period from 2010-2015 and during the making of the document an expert team was formed, and citizens were consulted too. The research in 2014 within the Cultural Policy as a Tool for Community and Regional Development project, included the evaluation of the first strategic document. Overall analysis of all cultural participants and cultural needs and habits of citizens was also done. All the data was used to create a two-year action plan in culture (2014-2015.) (Мрђа, Субашић, Опачић, 2014), and it will also present a base for development of new strategic document for a period from 2016-2020. Also, Pancevo is the only city in Serbia that recognizes a clear need for improving activities within cultural needs and habits of the youngest citizens, and it's currently working on defining the action plan in connecting cultural and educational institutions on the city level domain. Similar activity within a preschool education preceded that activity, through the cooperation agreement of Cultural Center of Pancevo and city Preschool Institution.

On the local government level, Secretary for Public Service and Social Issues is in charge for culture, and it oversees work and functioning of the cultural institutions. Aside of the Secretary, culture has been represented by a member in Executive City Council, Culture Council and Team for Implementation of Cultural Development Strategy 2010-2015.

When it comes to cultural infrastructure, Pancevo has a rich network of public cultural institutions. After Belgrade, the capital city, and Novi Sad, the administrative center of Province of Vojvodina, Pancevo has the largest number of public institutions in the culture sector. Another asset of the cultural sector is the existence of the large number of the institutions in the rural area of the city of Pancevo, which is rare in terms of organizing culture in Serbia these days.

There are 15 cultural instutions in Pancevo. Among them 11 (73\%) of polyvalent type (2 cultural centers in the city and 9 in towns), while in the protection of cultural goods domain, there are 3 cultural institutions (the Museum, Archive and Library). Pancevo has a rich civil sector too, and there are around 50 citizens associations currently active in the city itself and surrounding towns with culture as their primary activity.

All cultural institutions are financed in the domain of salaries, permanent expenses, programs within basic activities, current repairs and maintenance of the equipment from the City of Pancevo budget. The largest budget of all cultural institutions has 
Cultural Center of Pancevo. That is expected considering the fact that it is the most complex institution in the city. The smallest budget, according to the number of employees, have cultural centers in towns. When it comes to the income structure, the institutions greatly rely on their founder, from where they obtain the largest amount of funds. Cultural institutions represent only a small fraction of funds of the Republic and Province (not over $5 \%$ of budget, and often less than $1 \%$ of the annual budget).

One of the extremely positive measures of City cultural policy is a support to civil sector and individuals in culture, for improving cultural offer and strengthening individual and collective cultural force. Eleven years ago, City of Pancevo established a competition mechanism with defined methodology and work of the committee which is in charge of evaluating projects submitted and gives propositions for co-financing, with the Major giving the final word. Competition is for individuals, artists, students, informal groups and cultural organizations. The result of the good local government practice reflects in actualization of about 500 different projects, which contributes to affirmation of artistic and cultural creativity of individuals and organizations. Budget for the period from 2006-2009 was in average, 3.000.000 dinars per year, and in the following years those funds increased. Today they are $0.2 \%$ of overall city budget (this data is valid for the year 2014.)

Figure 5: Pancevo - city culture budget (2006-2013)

\begin{tabular}{|c|c|c|c|c|}
\hline \multirow{9}{*}{ 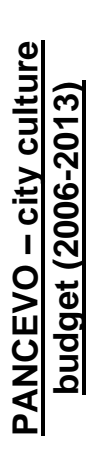 } & Year & $\begin{array}{c}\text { Total city budget } \\
\text { EUR }\end{array}$ & $\begin{array}{c}\text { Culture budget } \\
\text { EUR }\end{array}$ & $\begin{array}{l}\text { Culture share in total } \\
\text { city budget }\end{array}$ \\
\hline & 2006. & $31.443 .460,89$ & $1.923 .530,45$ & $6.1 \%$ \\
\hline & 2007. & $36.721 .928,23$ & $2.031 .891,93$ & $5.5 \%$ \\
\hline & 2008. & $46.208 .706,76$ & $3.007 .672,97$ & $6.5 \%$ \\
\hline & 2009. & $37.234 .969,20$ & $2.248 .992,14$ & $6 \%$ \\
\hline & 2010. & $29.128 .363,22$ & $1.826 .476,79$ & $6.3 \%$ \\
\hline & 2011. & $35.687 .500,03$ & $2.102 .994,64$ & $5.9 \%$ \\
\hline & 2012. & $39.156 .457,16$ & $2.173 .021,26$ & $5.6 \%$ \\
\hline & 2013. & $37.363 .406,09$ & 2.054 .821 .81 & $5.5 \%$ \\
\hline
\end{tabular}

Figure 6: Pancevo - Culture competition fund (2010-2013)

\begin{tabular}{|c|c|c|c|}
\hline \multirow{6}{*}{ 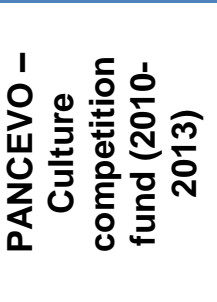 } & $\begin{array}{l}\text { Cultural projects } \\
\text { competition }\end{array}$ & Competition budget EUR & $\begin{array}{l}\text { Percentage of competition } \\
\text { funds in total city budget }\end{array}$ \\
\hline & 2010. & $16.502,44$ & $0.06 \%$ \\
\hline & 2011. & $68.454,66$ & $0.2 \%$ \\
\hline & 2012. & $50.009,97$ & $0.13 \%$ \\
\hline & 2013. & $72.714,79$ & $0.19 \%$ \\
\hline & 2014. & $98.034,20$ & N/A \\
\hline
\end{tabular}

Source: Мрђа, Субашић, Опачић, 2014: 80 
When it comes to amount of money per capita, most counties/cities in Serbia give between 5 and 8 EUR per capita annually (50.3\%). Pancevo is an example of a good practice in this domain too, because it belongs to a group of cities which give highest amount of money per capita for culture - around 16 EUR in average per year $(17.6 \%$ of the cities in Serbia give more than 14 EUR per capita) (Лазаревић, ed, 2011:11; Мрђа, Субашић, Опачић, 2014:80).

Figure 7: Pancevo - Culture fund per capita

\begin{tabular}{|c|c|c|c|c|c|c|}
\hline \multirow{9}{*}{ 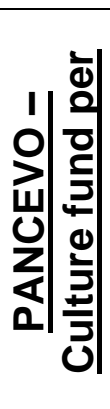 } & \multirow{9}{*}{ অ্ } & \multicolumn{2}{|c|}{ The number of citizens in county/city } & \multicolumn{3}{|c|}{$\begin{array}{c}\text { An average culture budget per capita over a period o } \\
\text { time }\end{array}$} \\
\hline & & \multirow{5}{*}{ Census 2002} & \multirow{5}{*}{127.162} & 2006. & 15.13 EUR & $1.272,31 \mathrm{din}$. \\
\hline & & & & 2007. & 15.98 EUR & $1.277,67 \mathrm{din}$. \\
\hline & & & & 2008. & 23.66 EUR & $1.926,05 \mathrm{din}$ \\
\hline & & & & 2009. & 17.67 EUR & $1.661,26$ din. \\
\hline & & & & 2010. & 14.36 EUR & $1.480,05$ din. \\
\hline & & \multirow{3}{*}{ Census 2011} & \multirow{3}{*}{122.252} & 2011. & 17.20 EUR & $1.753,76$ din. \\
\hline & & & & 2012. & 17.77 EUR & $2.010,84$ din. \\
\hline & & & & 2013. & 16.81 EUR & $1.901,61$ din. \\
\hline
\end{tabular}

Source: Лазаревић, ed, 2011:11; Мрђа, Субашић, Опачић, 2014: non-published report

In the context of the staff policy there are 179 employees in the cultural institutions and among them over $60 \%$ are females. Also, $45 \%$ of the employees have higher level of education.

Figure 8: Employees regarding education

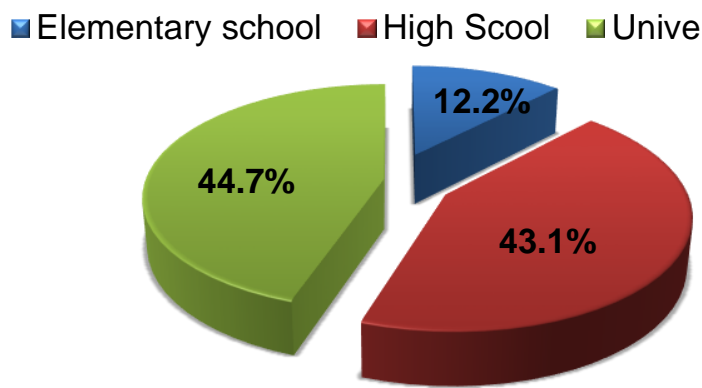

Source: Мрђа, Субашић, Опачић, 2014: non-published report

Figure 9: Employees according to gender

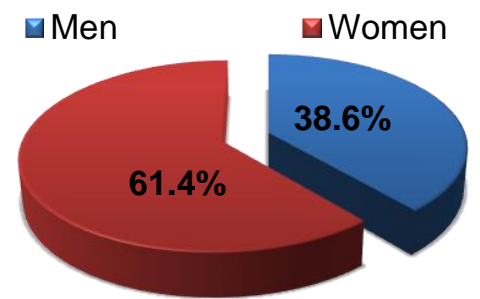

Source: Мрђа, Субашић, Опачић, 2014: non-published report 
The City of Pancevo developed a good practice of following cultural needs and habits of the locals. So within the aforementioned project in the IPA program Serbia-Romania, a detailed research of the cultural profiles of citizens in Pancevo was done, which significantly contributes to adequate defining of local cultural policy and sustainable development. In that sense, several very important data has been noticed.

\subsection{The most important results of the survey}

The citizens of Pancevo stated that culture is (very) important for the society $(70.7 \%)$, while only $6 \%$ consider culture little or not important. Still, one third of citizens of Pancevo rarely visit cultural events while only $7 \%$ can be considered regular audience. Citizens of Pancevo rarely can be seen in national minority theatres $(84.8 \%$ has never been in this type of theatre) while most often they visit Cultural Center (most often movie projections), and then the library. Based on the frequency of visiting cultural events, the audience can be divided into 3 categories, regular audience visits a cultural event at least once a month, periodical audience attends a cultural event $2-3$ times a year and/or rarely, and non-audience which can never be seen in any cultural event. Unfortunately, non-audience is the largest part of population with $60 \%$, while regular audience is of the least number.

Great statistical differences in attendance come with age groups. The younger surveyed visit city polyvalent centers, cultural events in non-conventional places of touring programs, cinemas and libraries more frequently. From this it can be concluded that visiting cultural events decline with the age. The biggest difference among generations is in visiting movie projections and libraries. $15 \%$ of young and $55.7 \%$ of older surveyed never go to cinemas, and $20.7 \%$ of young and $53.4 \%$ of older surveyed never go to libraries.

\section{Figure 10: Types of audience}

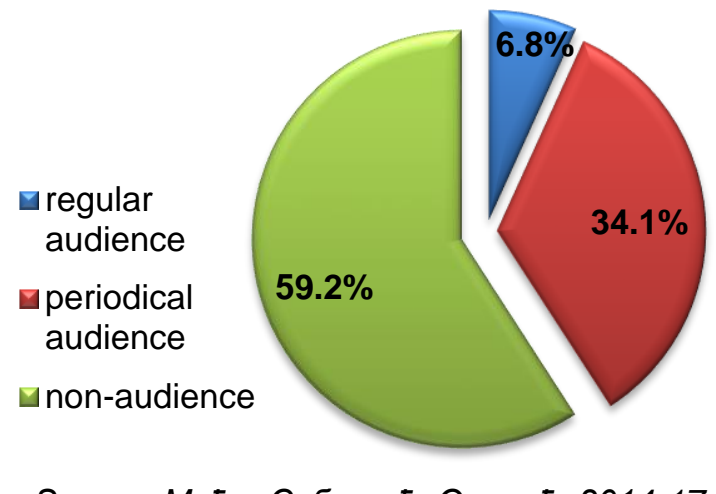

Source: Мрђа, Субашић, Опачић, 2014:17

Talking about a typical visitor of cultural events, there is a big difference between visitors of rural and urban areas. A typical visitor of cultural events in the city is a highly educated, younger female, up to 29 years of age, from the city area, and with the family budget over 800 EUR. When it comes to towns, profile of a cultural centers visitor shows 
that it is a younger male, up to 29 years of age, graduated from a secondary school and with a family income between 400 and 800 EUR.

Citizens of Pancevo (67.6\%) gladly visit city events, and give positive marks to the work of the local government and cultural workers organizing events. To the question up to what extent they are satisfied with the offer of the city events, over two third states that they are (very) satisfied, and less than $10 \%$ are not satisfied.

A typical profile of a visitor can't be concluded based on the answers. The only important characteristics is that he/she represents the young, up to 29 years of age. It should also be mentioned that although the city of Pancevo has a long tradition in organizing events that support ethnic communities heritage, 83.3\% citizens of Pancevo did not attend a single event of this type in the last three years. Cultural scene of Pancevo has a potential to satisfy the needs of its citizens. And this claim is supported by a fact that, when giving the most important event they attended in the last year, $82 \%$ of the citizens of Pancevo state events held in the city, while the ones giving the events in different cities or countries are extremely rare.

\section{Figure 11: Satisfaction with local cultural events}

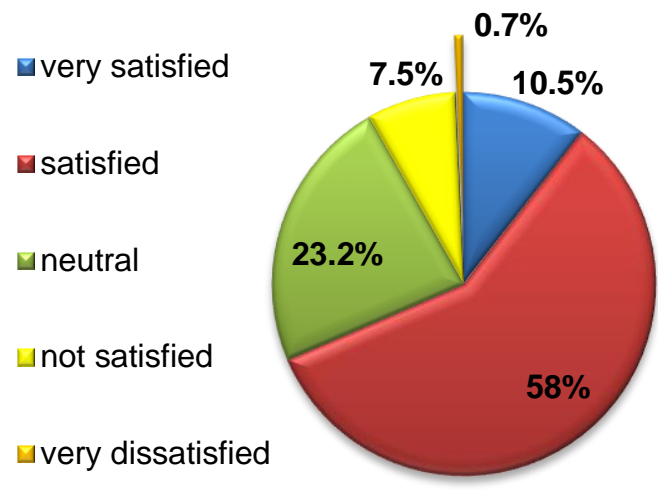

Source: Мрђа, Субашић, Опачић, 2014: 20

When deciding about a motive to attend a cultural event, large number of surveyees stated that the most important is that event is interesting and of a good quality, then the entrance fee, and also the time and the place of the event. Although there are no statistically important differences it has been noticed that the criteria for attending an event varies by the age of surveyees. Over a half of the young surveyees attend a cultural event based mostly on the theme of the event, and the same is with more than the third of the older surveyees. Although it is not significant there is a visible difference within family income of the surveyees. According to it, having a larger budget means less interest in the price of the event, and more interest in the theme of the event.

Getting informed is conditioned by the type of the event. Television cannot be avoided when informing of events, except when it comes to the cinema, which mostly uses posters to inform citizens. Internet is mostly used to inform of musical events, and when choosing books, citizens usually rely on friends recommendations. 
Several significant data can be concluded when it comes to the taste in different cultural domain.

Taste in music: Citizens of Pancevo prefer listening to pop music (one third of all answers), then folk music, and then rock music. It is interesting that classical music is on the 4th place. The age has a crucial effect when choosing a musical genre. There are clear tendencies in dropping interest in pop and rock music with the older audience, while the situation is reversed with folk music. There are significant differences in the education too - highly educated citizens lean toward pop, rock, jazz and classical music and move further away from folk music, which is mostly represented with the least educated citizens. (Мрђа, Субашић, Опачић, 2014: 69).

\section{Figure 12: Musical taste}

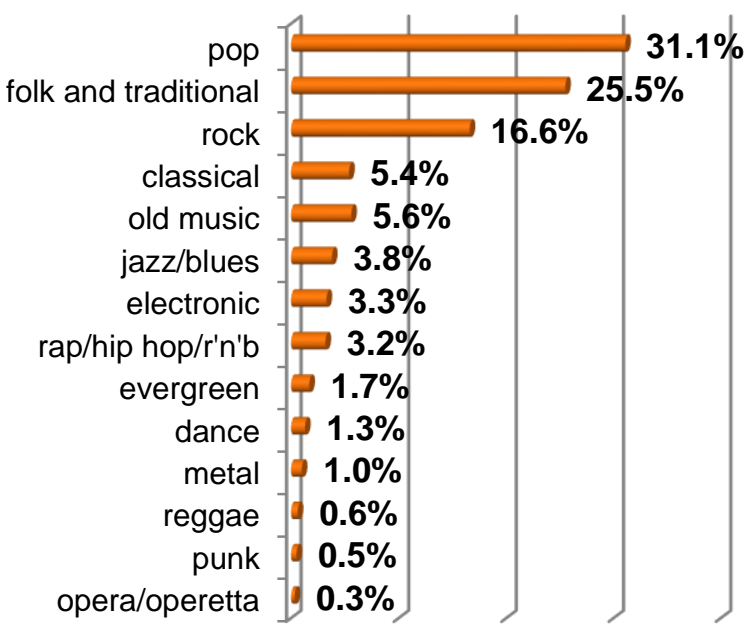

Source: Мрђа, Субашић, Опачић, 2014: 38

- Taste in theatre: Citizens of Pancevo prefer classical theatre, 44. 3\%, then modern theatre, $40.3 \%$, and they are least interested in the experimental theater, $4.3 \%$. When it comes to genre, citizens of Pancevo prefer comedies and dramas, and they least like musicals. Selection of the genre does not depend on the socio-demographic characteristics of the surveyees. (Mpђa, Субашић, Опачић, 2014: 70).

- Taste in literature: Citizens of Pancevo prefer reading classical novels, then romance and then historical novels. Men usually decide on action novels, epic fantasy, science fiction, thrillers and historical novels, while women more often choose romance and psychological novels. It can be concluded that citizens of Pancevo of lower education, as well as those from towns prefer 'simple' literature (comedies, romance) while the ones of the higher education and from urban areas lean to more demanding books (psychological, historical, scientific and biographies). (Мрђа, Субашић, Опачић, 2014: 70). 
Figure 13: Literary taste

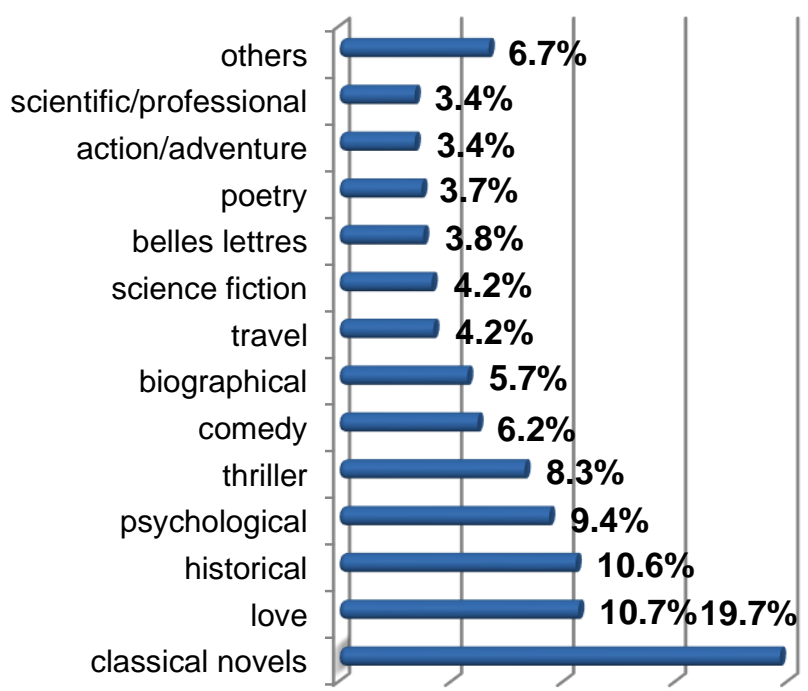

Source: Мрђа, Субашић, Опачић, 2014: 48

- $\quad$ Taste in movies: The largest number of surveyees decide on comedies as their favourite movie genre, and then action, thriller and dramas. Women prefer entertaining and romantic films in one hand, and hard life stories on the other. Men prefer fast, scary films and those with lots of fantastic elements. Besides sex, the age plays an important role when choosing a movie genre. Action movies are more popular with the older surveyees and it is a favourite genre to people older than 49 years of age. On the other hand, young and middle-aged prefer comedies. (Мрђа, Субашић, Опачић, 2014: 71).

Figure 14: Taste in movies

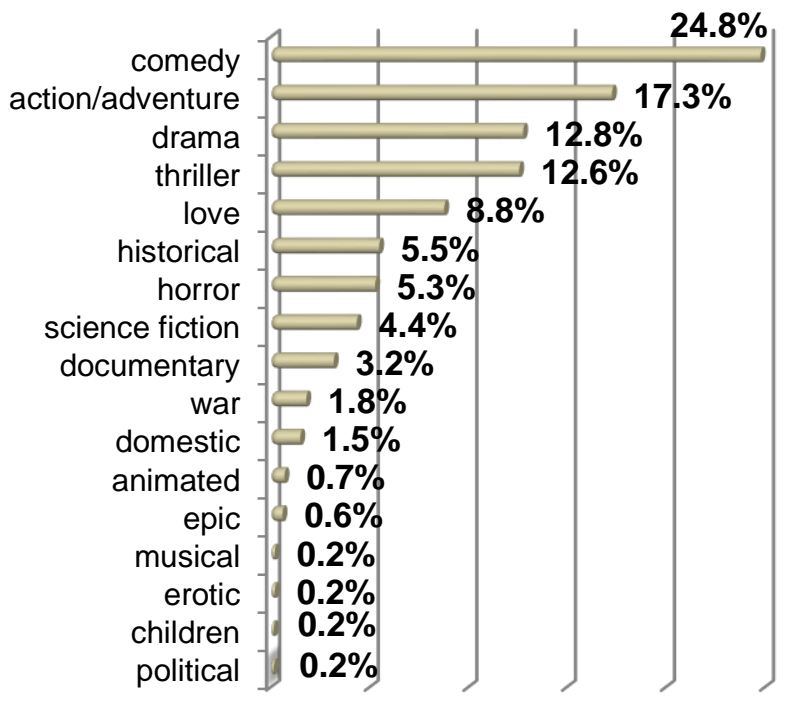

Source: Мрђа, Субашић, Опачић, 2014: 53 
An important part of the Pancevo identity is its rich tradition and (non)material heritage, but also contemporary art. Therefore, one of the important aspects in cultural development is cultural tourism. When concerning tourism, citizens pointed out that the key element of its development is culture, not based on programs, but in presentation of sites and starting up festivals.

According to citizens, the most authentic symbol of the city is the old city core with its landmarks from the 18th and 19th century. Local government supported the project Visit Pancevo in the city contest 2014 and 2015 taking into an account the importance of the cultural heritage and development aspect of tourism and also appreciating citizens' opinion. This project in its focus has promotion of heritage through culture routes, visiting institutions and landmarks (http://www.pancevo.com/poseti-pancevo, accessed 08.06.2015).

An example of appreciating citizens' opinion is also visible in the contemporary art domain. According to citizens, Pancevo should develop through branding itself as a festival city. They state that Pancevo lacks music and film festival the most (Mpђa, Субашић, Опачић, 2014: 72). Considering that, the city government supported organization of the film festival PAFF (Pancevo Film Festival) in the city contest in 2014. and 2015. (http://www.pancevofilmfestival.com, accessed 08.06.2015.)

All previously stated show that research within culture can be a significant base for defining cultural policy in the service of sustainable development.

\subsection{Challenges of the local cultural policy in the service of the sustainable development - the City of Pancevo}

Even though in the local cultural policy domain, Pancevo represents an example of good practice in Serbia, there are areas which should be improved in the context of defining developing policies.

According to the assessment of the local government representatives, basic problems in the city culture are: insufficient care for cultural and historical heritage, lack of funds for restauration of the buildings and investing in infrastructure, insufficient cooperation among cultural institutions on the local level (Лазаревић, 2011: 49). Representatives of the cultural institutions and organizations as well as citizens agree on the fact that these are the key points to work on. During the survey conducted in 2013 they stated priorities concerning the problems mentioned (Мрђа, Субашић, Опачић, 2014: 100, Мрђа, Субашић, Опачић, 2014: 59). 


\section{Figure 15: Activity priorities in culture}

\begin{tabular}{|c|c|c|}
\hline & Priority ranking - cultural institutions & Priority ranking - citizen associations \\
\hline 1 & $\begin{array}{c}\text { Preservation of tradition and protection of cultural } \\
\text { heritage }\end{array}$ & $\begin{array}{l}\text { Preservation of tradition and protection of cultural } \\
\text { heritage }\end{array}$ \\
\hline 2 & $\begin{array}{l}\text { Equipping/renovation/reconstruction of the cultural } \\
\text { institutions }\end{array}$ & Contemporary art \\
\hline 3 & Larger number of cultural programs & Better promotion of cultural programs \\
\hline 4 & $\begin{array}{l}\text { Greater variety of cultural programs according to the } \\
\text { audience age }\end{array}$ & Promoting multiculturalism \\
\hline 5 & Greater stress on development of cultural tourism & Greater stress on development of cultural tourism \\
\hline 6 & $\begin{array}{c}\text { Greater variety of cultural programs according to } \\
\text { type of programs }\end{array}$ & Development of the international cooperation \\
\hline 7 & Development of the international cooperation & Larger number of cultural programs \\
\hline 8 & Promoting multiculturalism & $\begin{array}{l}\text { Equipping/renovation/reconstruction of the cultural } \\
\text { institutions }\end{array}$ \\
\hline 9 & $\begin{array}{l}\text { Better promotion and support of cultural-artistic } \\
\text { amateurism }\end{array}$ & Adjusting programs to the audience needs and taste \\
\hline 10 & Equipping old industrial facilities for cultural needs & Equipping old industrial facilities for cultural needs \\
\hline
\end{tabular}

Source: Мрђа, Субашић, Опачић, 2014: 100

\section{Figure 16: Activity priorities in culture}

\begin{tabular}{|c|c|}
\hline \multicolumn{2}{|c|}{ Priority ranking - citizens } \\
\hline $\mathbf{1}$ & Preservation of tradition and protection of cultural heritage \\
\hline $\mathbf{2}$ & Greater variety of cultural programs according to the audience type \\
\hline $\mathbf{3}$ & Larger number of cultural programs \\
\hline $\mathbf{4}$ & Equipping/renovation/reconstruction of the cultural institutions \\
\hline $\mathbf{5}$ & Adjusting programs to the audience needs and taste \\
\hline $\mathbf{6}$ & Better promotion of cultural programs \\
\hline $\mathbf{7}$ & Greater variety of cultural programs according to type of programs \\
\hline $\mathbf{8}$ & Contemporary art \\
\hline $\mathbf{9}$ & Reactivation of industrial heritage \\
\hline $\mathbf{1 0}$ & Greater stress on development of cultural tourism \\
\hline
\end{tabular}

Source: Мрђа, Субашић, Опачић, 2014: 60-61

\section{Financing and infrastructure}

An average culture share in the overall city budget in the last three years is $5.6 \%$, or nominally around 5 million EUR or, in average, less than 350.000 EUR per institution. This data shows that there are great challenges in the domain of finances. The situation becomes worrying regarding culture budget structure, because the largest amount of funds goes to the salaries, and the least amount is for program activities. Only about $9 \%$ of budget is invested in the organization of events. Only city cultural centres invested more than $10 \%$ of their budget into programs. 
Figure 17: Expense structure

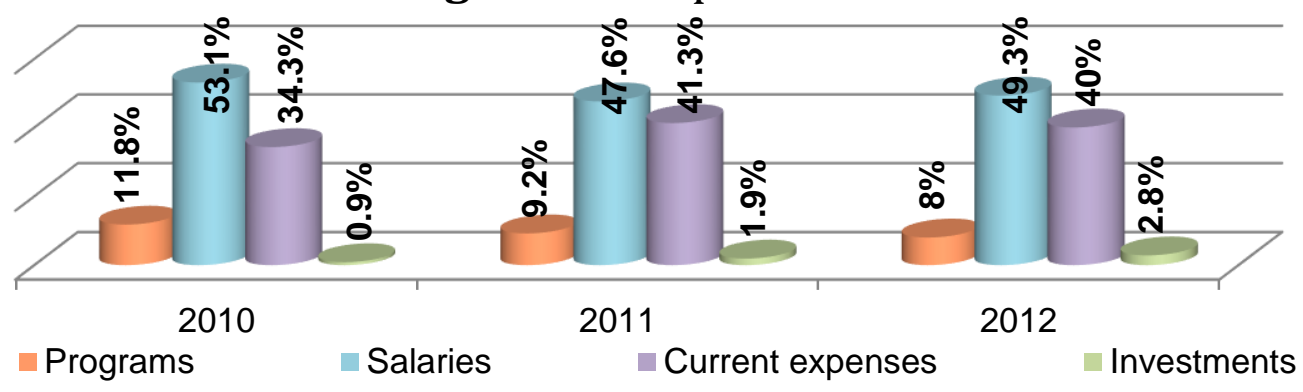

Source: Мрђа, Субашић, Опачић, 2014: non-published report

When discussing the sources of financing, challenges are even more visible. All cultural institutions mostly rely on the city budget. Other sources are insignificant. Investments of Republic of Serbia and Province of Vojvodina together do not exceed 1\% of the annual budget of all institutions. Foreign funds are obtained only by the Cultural Center and only in 2010 (Мрђа, Субашић, Опачић, 2014: 81).

Figure 18: Income structure

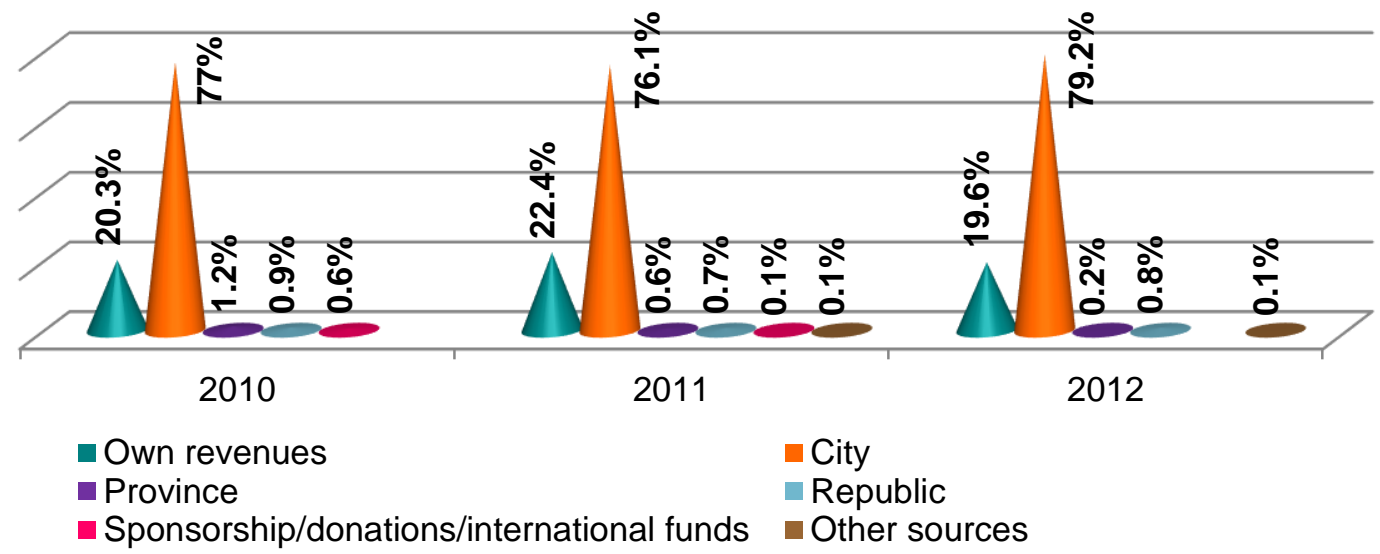

Source: Мрђа, Субашић, Опачић, 2014: non-published report

One of the problems in financing is maintenance of cultural institutions and technical equipment. Also, two institutions, (the Archive and Museum), are in buildings which are cultural monuments. That makes maintenance even more difficult, because special laws in restauration and reconstruction must be obeyed. The biggest problems are cultural centers in rural areas which don't even have basic conditions to function such as electricity, roof etc. One cultural center in a village don't even have a facility and organises events out in the open or uses a restaurant. Although the city government makes efforts to obtain funds for cultural centers in villages, it cannot meet all the challenges presented.

Contemporary trends in culture demand constant acquiring of equipment for special types of programs and permanent activities (projectors, screens, lights, sound, 
equipment for digitalization). The largest number of cultural institutions do not own that equipment and they are forced to rent it.

Considering all of the above, it can be concluded that institutions need to be stimulated in finding alternative ways of funding themselves. Some of the stimulation models can be education in project-writing and applying to contests; they can also be requests to open institutions towards civil sector which can provide not only the necessary knowledge in the alternative finance domain, but also the means brought by a partnership. It is also important to make a list of priorities for investments which will improve inadequate facilities and provide new ones where there is a need (Mpђa, Субашић, Опачић, 2014: 81).

Employees in the cultural institutions

According to executives of the cultural institutions in the city, the factors that affect decision -making in cultural offer are support of the government administration, audience, cooperation with various cultural workers, quality of human resources and management. On the other hand, executives of the cultural centers in villages state that cooperation with various cultural workers, quality of human resources, audience and their own funds are crucial in making decisions about cultural offer. All the factors stated above greatly depend on the personnel policy in culture.

Although salaries are the biggest expense in the budget, executives of institutions state that the existing personnel is not enough and/or they don't have the knowledge or skills for various programs. Executives of the cultural institutions in villages name lack of personnel as their biggest problem. The problem in the institutions in the city area is that personnel are not able to meet needs of the audience and contemporary cultural trends. Hence, the need for obtaining funds is significant. These funds would provide continuous education of cultural personnel and starting new policies in this segment of cultural work. Also, it is necessary to develop detailed system of evaluation as a model to motivate cultural personnel.

Executives of the institutions in the city area and representatives of the citizens associations are very interested in professional development of the employees, while the executives of the cultural centers in villages are less interested in that subject. Most executives and presidents of the city associations are interested in attending courses themselves in order to improve their managerial skills.

Cooperation

Although all cultural institutions and organizations representatives stated that they cooperate, it is obvious that the cooperation is not satisfying. The research showed that the cultural institutions and organizations mostly cooperate in logistics support (facilities and equipment) and in touring events, but there is no cooperation when it comes to development of the ideas, programs and projects. Joint projects could also represent bases for alternative funding (Мрђа, Субашић, Опачић, 2014: 77-78). Local government representatives recognize that problem too, and they think that lack of cooperation might be one of the greatest challenges in the future. It is also necessary for cultural institutions to turn to connecting with institutions in other cities, in Serbia and Pancevo as well as abroad.

Cooperation between departments - although cultural tourism is considered to be one of the important areas in development and it is in action plan for 2014. - 2015. , it is necessary for cultural institutions to open more to promotion of their contents for 
tourism. Also, innovative and more interesting approach to the audience is necessary, an approach that follows the contemporary trends in development of cultural tourism.

Speaking of relation among culture and economy in general, a greater support in development of creative sector is necessary, mainly by mapping all participants, and then encouraging networking and business development in creative economy domain. This area is not considered enough within Cultural Development Strategy 2010.-2015. This could be a recommendation for the future strategic plans, not only in the area of culture, but also economy and city development strategy.

The research shows that cooperation with media could also be improved. Focus groups concluded that cooperation with media mainly comes down to reporting from events, but it lacks program promotion, especially in the rural area. It should also be pointed out that the institutions agreed on the fact that cooperation with media can only be achieved on the local level, but it is not developed when it comes to regional and national media. Citizens also agree that culture is not promoted enough outside the City of Pancevo. Over a half of surveyees think that visibility of the cultural programs of Pancevo is on the low level in Province and Serbia, or local contents are not promoted at all. Over $40 \%$ of citizens of Pancevo think that information on cultural offer of Pancevo never reaches other countries at all.

Cooperation between sectors - civil sector participants in culture often are not able to provide space for their work and the artistic expression, and doors of cultural institutions remain closed to them. As a consequence it often has shutting down of organisations and ruining cultural diversity. It also diminishes possibility for obtaining means from international funds (which, most often, are not open for public institutions). Also, a weak point of cooperation between sectors is connecting to the private sector, which, at the moment, is not motivated to get involved in culture (because of the lack of measures on the state level, which stimulate corporate responsibility). Still, their participation on the local level could provide double benefit - on one hand promoting work of the private sector, and on the other helping institutions, through improving programs and attracting audience.

International cooperation is yet another potential for development policies of institutions and the City, which isn't used enough. The City of Pancevo has a great possibility of international cooperation because of its geographic position and ethnic diversity. However those possibilities are much more used by the civil sector in culture (especially folklore groups) while the public institutions don't use those possibilities. That should be changed.

Citizens' opinion about culture

Most, namely one third, of citizens of Pancevo is satisfied by the cultural offer in the city up to a medium level. More than one quarter is satisfied, while $1.7 \%$ are very satisfied with cultural events in Pancevo. It can be concluded that there is a small number of those who are unsatisfied- $8.4 \%$ are unsatisfied, and $1.6 \%$ are extremely unsatisfied by the cultural offer. That leads to a conclusion that designers and torch bearers of the cultural offer manage to satisfy cultural needs of the citizens to a great extent. Still, it should be mentioned that one quarter of the citizens don't have an opinion about cultural offer so it is questionable if their needs are met or if it is a result of their lack of interest in culture contents so they should be woken up. 


\subsection{Satisfaction of citizens of Pancevo with the cultural offer}

Certain sociodemographic characteristics influence differences in level of satisfaction with cultural offer in Pancevo. Although differences according to age are not statistically significant, it can be concluded that the youngest citizens are the least satisfied by contents. Also, when it comes to education, citizens of lower education are less critical towards cultural offer and/or less interested in culture. Finally, the living area makes the biggest difference. Over a third of citizens from rural area don't have an opinion on cultural offer, whereas over $15 \%$ of citizens from urban area have one. This result leads to a conclusion that polyvalent centers in villages have a huge mission to motivate their population, ie. non-audience, to participate in cultural events in the village or town where they live (Мрђа, Субашић, Опачић, 2014: 7-8).

Figure 19: Satisfaction of citizens with cultural offer

$\square$ very satisfied
$\square$ satisfied
$\square$ somewhat satisfied
$\square$ unsatisfied
$\square$ very unsatisfied
$\square$ without an opinion

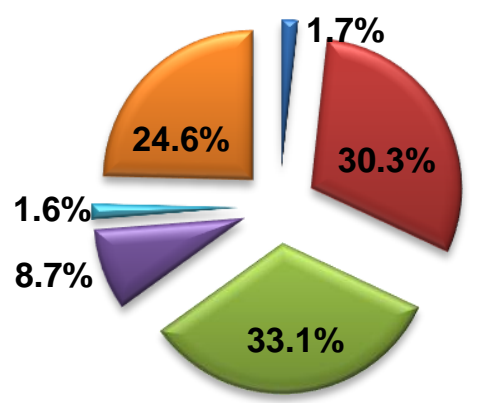

Source: Мрђа, Субашић, Опачић, 2014: 7

Reasons for discontent mainly originate in insufficiently diverse cultural offer according to the audience type. On the other hand, citizens are the least critical towards cinema and theatre contents, considering that there are enough of them (Мрђа, Субашић, Опачић, 2014: 9).

Figure 20: Lacks of the cultural programme

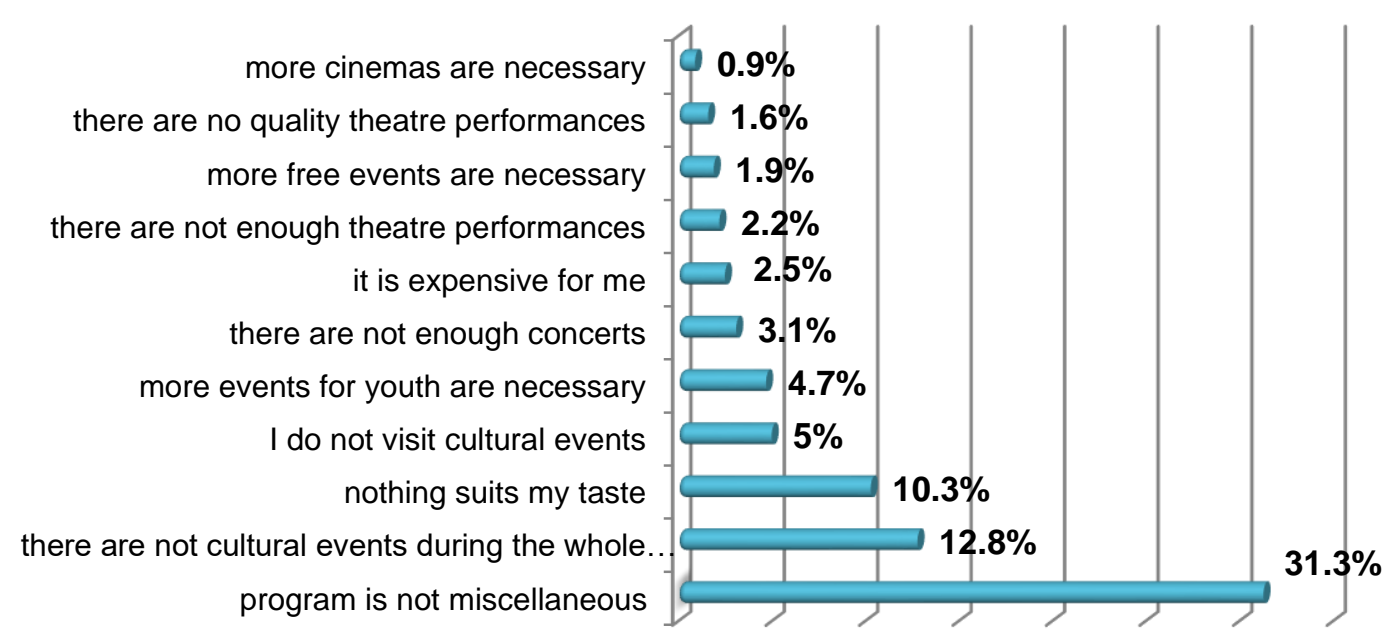

Source: Мрђа, Субашић, Опачић, 2014: 9 
When asked to compare cultural offer during last two years $(2012,2013$.$) , over 40 \%$ of citizens think that cultural offer has not changed ie. it is on the same level, which suggests that some innovations are required in culture. Still, it is very worrying that over a third of the citizens were not able to compare cultural offer in Pancevo during 2012 and 2013 . Over $10 \%$ of the citizens think that there were less cultural events in 2013.

According to citizens of Pancevo, room for improvement is largest in the area of improving diversity of the programs and then in the area of availability of contents. This result is, to a smaller or larger scale, the same as answers of respondents about main reasons for (dis)satisfaction by cultural offer of Pancevo, where $31.3 \%$ of respondents stated insufficient diversity. Four citizens explicitly expressed the lack of programs for retired people, ie. for the oldest population (Мрђа, Субашић, Опачић, 2014: 35).

\section{Figure 21: Most significantly improved cultural area in Pancevo}

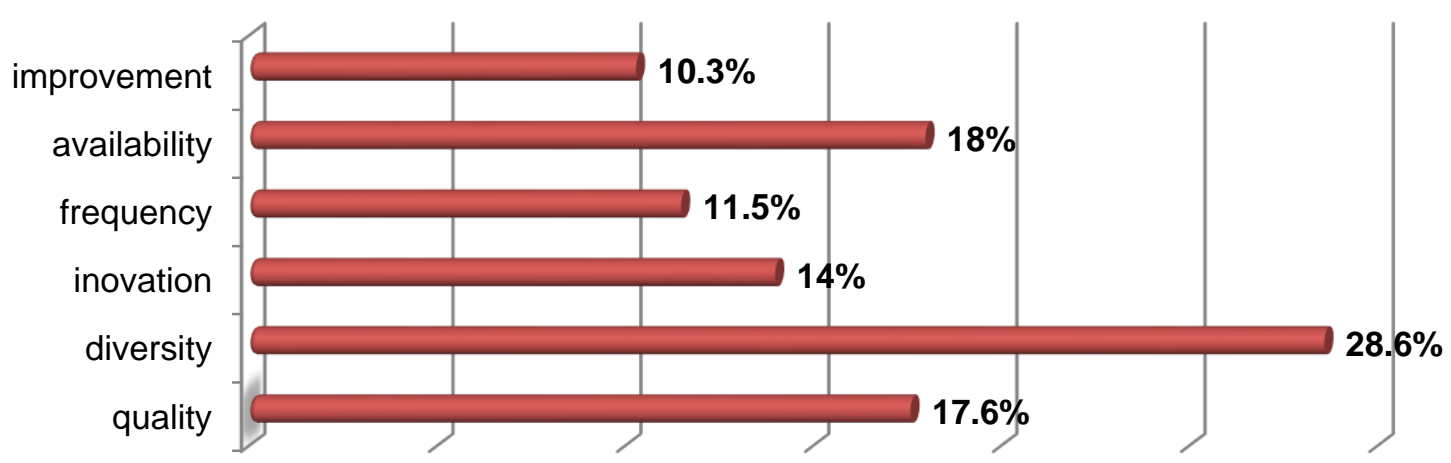

Source: Мрђа, Субашић, Опачић, 2014: 35

Based on the most frequent answers of the surveyees it can be concluded that diversity and availability in the answers largely overlap, and that obvious lack in cultural offer in Pancevo are contests for oldest and highly educated population within the city area and towns. This is the direction cultural institutions should be aiming at in improving their cultural offer. Highly educated young people in the city of Pancevo think that contents are not innovative enough, therefore considering the needs of young can be one of the missions of cultural institutions. Highly educated, middle-aged citizens most often name increase of contents frequency as means of improving cultural life.

Considering all of the above, cultural institutions should implement practice of researching the needs of special types of audience, which could improve cultural offer as well as citizens' content (Мрђа, Субашић, Опачић, 2014: 35).

When it comes to spreading culture to alternative facilities and its greater presence in the life of citizens, the largest number of questionees think that cultural contents should be expanded into parks, and that they are already present enough (or they don't belong there) in cafes and restaurants. The other most important alternative facilities are facilities of cultural and industrial heritage, and only around 10\% of surveyees don't agree. Citizens of Pancevo think that culture should be present in the city streets too, which could be used by the cultural institutions, if not as a space for programs, then as a place for marketing and animation of (non)audience. 
It is important to point out the large number of answers stating that cultural contents are limited to the city area and that they are not present enough in towns and city blocks- only $5.4 \%$ of questionees think that culture should not be extended to unpopulated places, and $11.4 \%$ has the same opinion about city blocks (Мpђа, Субашић, Опачић, 2014: 36-37).

Previous research of the Center for Study in Cultural Development (Cultural Practice of Citizens of Serbia, Aging Culture and Senior Citizens in Culture, Cultural Needs of University Students in Serbia, Cultural Needs of High-school Students in Serbia) showed that poor economic situation of Serbian citizens is the common reason for not attending cultural events.

According to Poles of Cultures research, a little over a quarter of citizens of Pancevo think that entrance fees for cultural events in the city are (very) expensive while a little over one fifth of citizens think that they are (very) cheap.

Education and family income affect the opinion on entrance fees the most. One third of the citizens with only elementary school degree think that entrance fees for cultural events in Pancevo are (very) expensive. The same opinion have a little over $20 \%$ of those with university degree. Also, more than a third surveyees (38.2\%) with monthly income under 200 EUR and a fifth (20.8\%) with monthly income over 800 EUR think that entrance fees for cultural events are (very) expensive.

Figure 22: Entrance fees

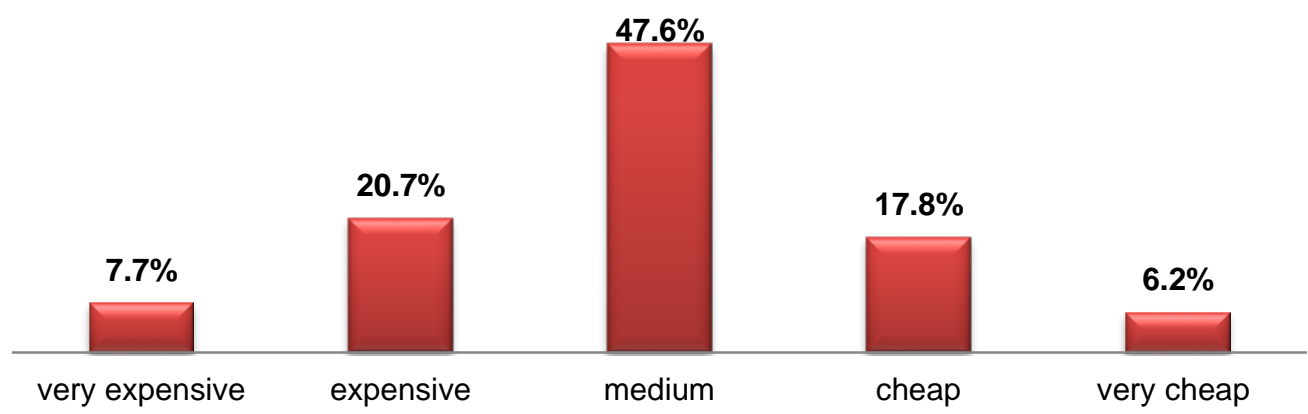

Source: Мрђа, Субашић, Опачић, 2014: 22

When it comes to the type of the programs citizens of Pancevo think that entrance fees for plays, concerts and touring events are (very) expensive, while the cheapest entrance fees are for KUD (folklore troups) and library membership (Мрђа, Субашић, Опачић, 2014: 22-23). 
Figure 23: Entrance fees according to event type

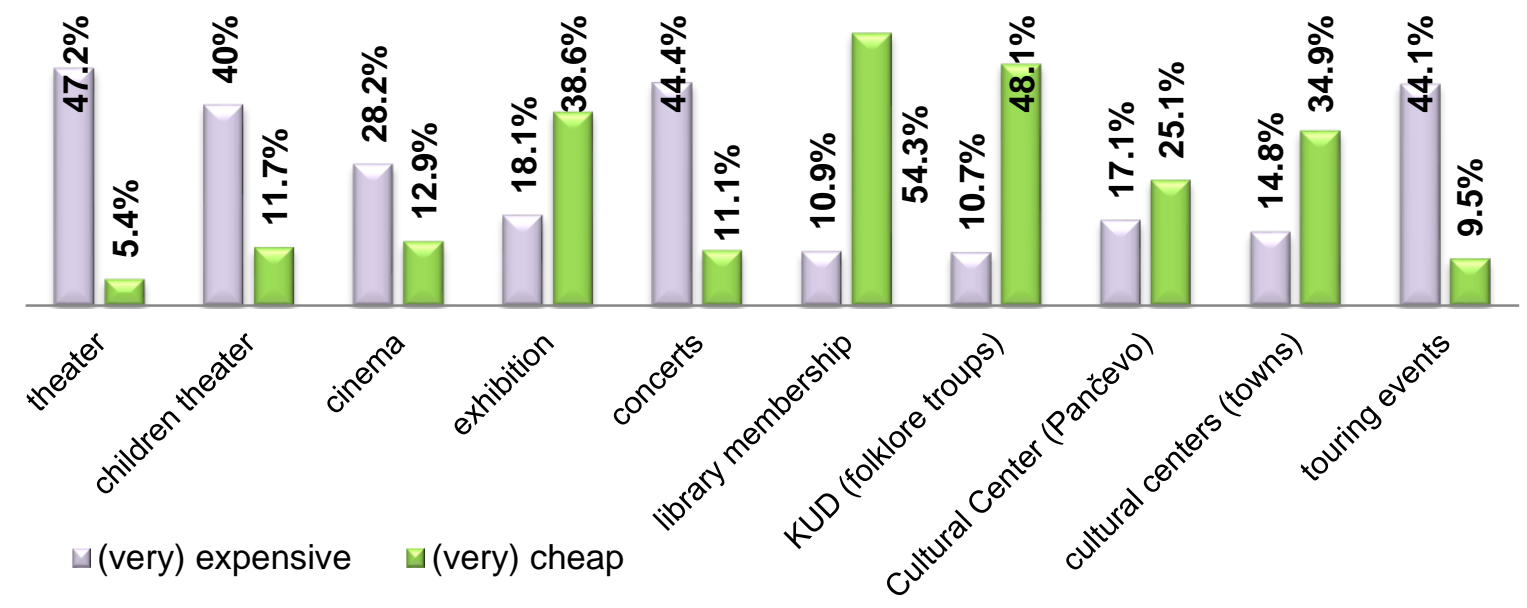

Source: Мрђа, Субашић, Опачић, 2014: 23

When it comes to citizens' interest for cultural strategic plan, it is, as expected. The strategic plan is within City Legislation Law and citizens have no interest in it, or can't contribute it. Although the City of Pancevo adopted its first strategic document in 2009, $82 \%$ of citizens of Pancevo aren't aware that such document exists. Also, only $12.8 \%$ of citizens express a desire to participate in a creation of such document, and almost half of them think that they can contribute by using their knowledge. Over a third of interested would like to have a possibility to comment on a finished document and little over $15 \%$ would like to participate in a public debate prior to adopting it (Мрђа, Субашић, Опачић, 2014: 22-23). Because of that it is very important to increase the role and interest of public through some kind of campaign when adopting these key documents. It is the only way of securing transparency of the whole process. It is a positive thing that City of Pancevo had a public debate when adopting the first strategy and that practice should be continued using every type of motivation for as big public participation as possible.

Institutions on audience

An important segment of the research in 2013-2014 was the analysis of the cultural institutions work, and especially realization and attendance of various programs.

- Polyvalent centers

- Theatre programs

Although the City of Pancevo doesn't have a theatre as a separate institution, all cultural centers enable the audience to enjoy theatre plays. However, only Cultural Center of Pancevo has its own production, and does co-production with theatres from other cities in Serbia. In urban and rural part of the city, there are over a hundred plays per year, in average, and half of that is realized by Cultural Center of Pancevo.

When it comes to the audience, the number of total theatre audience, according to obtained data, is roughly on the same level in all three reference years, with the slight 
increase in 2012. That can be an indicator of not animating enough (non)audience to visit theater. Because of that it is necessary for institutions, most active in this segment of culture, to develop a marketing strategies and ways to attract citizens to 'theatre' (Мрђа, Субашић, Опачић, 2014: 82).

Figure 24: Tendencies of theatre audience in total

\begin{tabular}{ccc}
\hline & 23598 \\
\hline 21780 & 21962 & \\
\hline 2010 & 2011 & 2012
\end{tabular}

Source: Мрђа, Субашић, Опачић, 2014: non-published report

\section{- Music programs}

The largest number of cultural events in Pancevo are music programs with around 200 per year. Music and theater events are organized in all cultural centers in urban and rural areas of Pancevo. Still, the largest number of visitors and programs visited the most, are those in cultural centers in the urban area of the city.

Regarding the audience, the number of music events visitors are on constant rise from year to year, unlike theatre plays audience.

Figure 25: Tendencies of concert audience in total

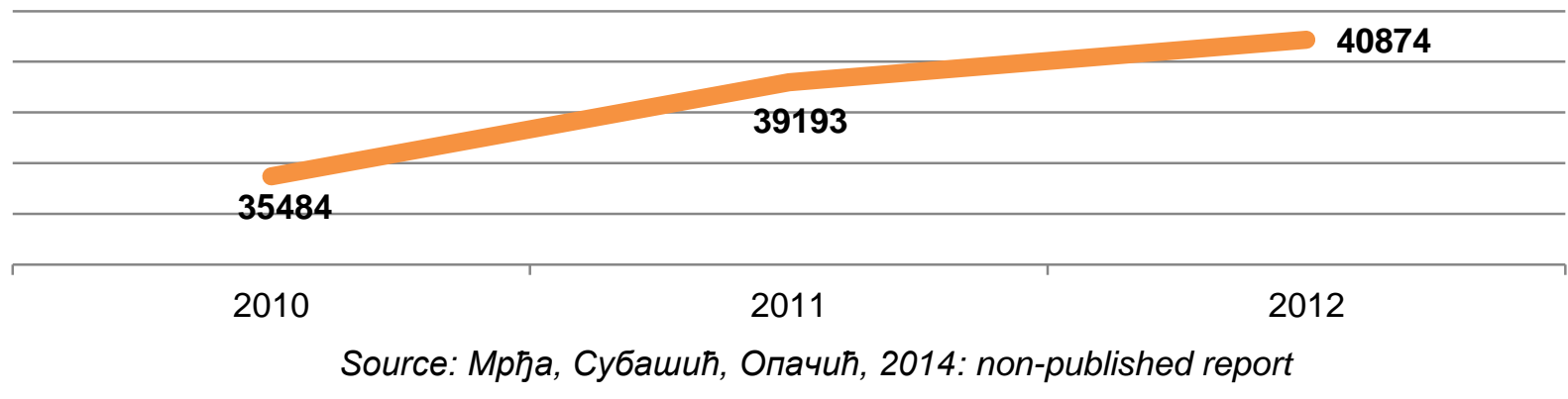

- Exhibition programs

Audience in the City of Pancevo can enjoy over 120 exhibitions per year, which are mostly organized in the Cultural Center Gallery, in the urban area of Pancevo. Their main feature is that they last for several days or weeks, and because of that these programs have the largest number of visitors- over 50.000 art lovers per year. However, this audience experiences a decline in number as well, in comparison to the first referenced year within the researched period. It should be pointed out that exhibits in polyvalent centers in Pancevo are almost always free of charge, which makes it hard to have statistics through number of tickets sold. Because of that some institutions gave rough number of visitors. 
Figure 26: Tendencies of exhibition audience in total

57735

51891

2010

2011

2012

Source: Мрђа, Субашић, Опачић, 2014: non-published report

- Cinema programs

Only Cultural Center of Pancevo has regular cinema projections, and plays 3D movies. Movies in the cinemas in rural areas are extremely rare. That is exactly the reason why of 640 projections in total per year, around 600 are realized in Cultural Center of Pancevo.

It should be pointed out that audience significantly varied in the researched period and had a significant drop in 2012 in comparison to 2011. (36.5\%). Also, cinema projections are extremely rarely visited, because, in average, there are only 27 viewers per projection.

This situation leads to a conclusion that Cultural Centre, as the leading institution in the cinema business in Pancevo, should find a way to attract lost audience and bring new ones: by better marketing, better organization and meeting audience needs - enabling booking, adjusting projections for children to parents working hours, obtaining digital equipment for better picture quality (Мрђа, Субашић, Опачић, 2014: 82).

Figure 27: Tendencies of cinema audience in total

\begin{tabular}{ccc}
\hline 16725 & 22969 & 14586 \\
\hline 2010 & 2011 & 2012 \\
& Source: Мрђа, Субашић, Опачић, 2014: non-published report
\end{tabular}

- Institutions for preservation

- Library activity

Library activity is connected to the PancevoCity Library and departments in all surrounding villages. The City Library is the only one withthe native collection - over 10.000 units. Literature for children is the most represented in the Central Library, with a quarter of a total book fund. On the other hand, publications in languages of national minorities are in largest number represented in the Library of Jabuka, around $30 \%$ of total book fund.

The largest number of library members are children in almost all library departments and Central Library as well, making a quarter of all members. Still, the youngest citizens 
of Pancevo are not, at the same time, the most devoted readers. Children borrow four books from the Central Library a year, while grown-ups borrow five, and in towns the statistics is most drastic (Мрђа, Субашић, Опачић, 2014: 83). This data points to a conclusion that children become members of the library when starting elementary school, but rarely use its capacities. For that reason the Central Library and library departments in towns and villages should develop mechanisms to animate and advertise, in order to attract the youngest citizens, who will become regular visitors of libraries and library programs. That will contribute to sustainable cultural development in cultural institutions in Pancevo.

Figure 28: Tendencies of all libraries members in total 2010-2012

\begin{tabular}{ccc}
\hline $14.1 \%$ & $14 \%$ & $13.6 \%$ \\
\hline & & 2012 \\
\hline 2010 & 2011 & Source: Мрђа, Субашић, Опачић, 2014: non-published report
\end{tabular}

Figure 29: Members of Central Library in the past 8 years

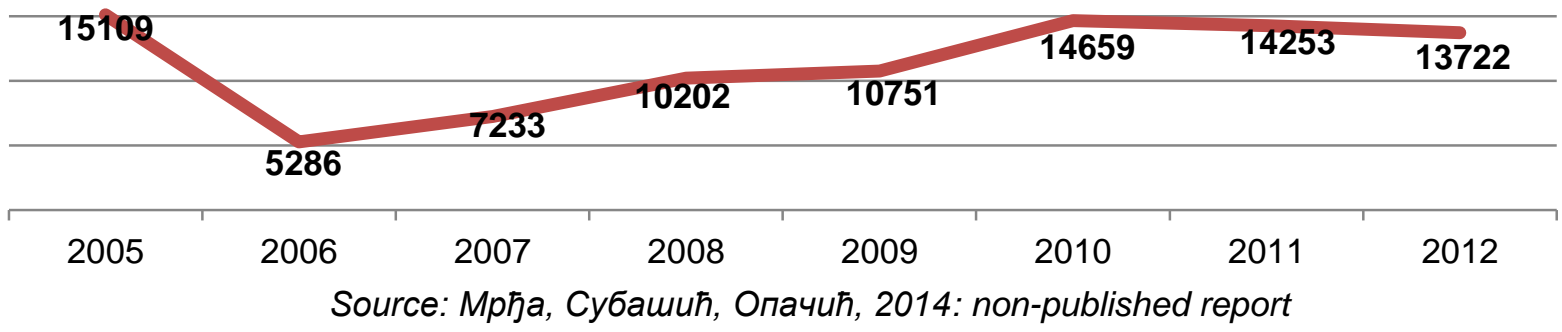

\section{- Other institutions for preservation}

In the questionnaire used during the research in 2013, the data on number of programs, besides the Library, stated only Archive, while the Museum of Pancevo and Institute for Protection of Cultural Monuments do not list additional programs. However the Center for Study in Cultural Development data, referring to the period 2007-2009 show that the Museum of Pancevo organizes additional cultural programs (exhibitions, lectures, workshops)(Лазаревић 2010: book 3, 51). Also, the Museum organizes cultural programs regularly, and works on improving educational department, which can be seen on the internet page of the Museum of Pancevo (http://www.muzejpancevo.rs/, accessed 10.06.2015). In the past two years, this cultural institution has attracted its audience through social networks. It also relies on cooperation with the civil sector more, mostly in preparing mutual programs and finding alternative ways of funding.

History Archive of Pancevo is active in exhibiting, with special facility for those purposes. Around 10 artistic and historical exhibitions a year are being held in that facility, while lectures and workshops are lot less organized in the Archive. However, to attract audience it is necessary to improve marketing and animation, cooperation 
between sectors, especially civil sector and cooperation with other cultural institutions. With all that, this cultural institution can become an important factor in cultural development in Pancevo.

\section{Conclusions}

Although the City of Pancevo has a distinctive identity on the cultural map of Serbia, several segments need improving in order to make cultural policy and sustainable development better. In the previous work it could be seen that, the City of Pancevo is in a high position when compared to national cultural policy, but almost identical challenges stand before cultural development in the Republic and local level, too. Sociological research in 2013, within Poles of Culture project, pointed to many deficiencies but also provided several recommendations.

Since the City of Pancevo has a City Cultural Development Strategy for a period from 2010-2015., it is necessary to continuously work on adopting such documents, not only in the department of culture, but in economy and youth care. These three departments should be connected while making these plans. Also, cultural institutions should adopt strategic plans for their own development and also development of the city culture. Those plans should be coordinated with priorities stated in City Cultural Development Strategy.

Participants in culture should constantly be informed on cultural needs and habits of citizens. Because of that it is necessary to do an audience survey on the local level every 3 to 5 years. Audience research practice should be applied on the cultural institution level too, and institution should coordinate animation and results of the research. Constant work on networking cultural institutions for project realization is necessary in order to get satisfied audience, as well as networking with the civil sector, which could contribute to obtaining additional financial funds. Cultural institutions should include media in their work, which would announce all cultural programs in due time. This recommendation is pointed out in the Action Plan for 2014-2015, too and starting an internet portal for culture has been suggested, which will present all cultural institutions and events on the city level (Мрђа, Субашић, Опачић, 2014: 117). One of the methods which would also improve programs and attract audience is making a culture calendar, which would present all activities on the annual level, and that would prevent organizing overlaping cultural events (Мрђа, Субашић, Опачић, 2014: 110).

Municipal Assembly of Pancevo should meet the needs of all participants in culture through trainings and education, contributing to more efficient functioning of culture, and it should also find ways to provide facilities for cultural institutions and cultural associations as well. When it comes to cultural heritage, which represents a huge potential of City of Pancevo, a list of priorities for reconstruction and revitalisation should be made and continuously worked on. 
One of the important goals to improve cultural policy of the City is giving a greater support to creative economy, mapping creative workers, and their networking. Action Plan for 2014-2015 lists defining special measures on city contests focused on cultural industries and creative sector, as one of the activities, and departments of culture, economy and rural development should be involved(Мрђа, Субашић, Опачић, 2014: 111). Within creative sector development, cultural tourism should be developed through branding the City as a place rich in industrial heritage and as a festival city. Pancevo could be branded in the movie world too, because it was a scenery for many Yugoslav and Serbian movies, which can help develop movie tourism and attract foreign producers (http://www.ekapija.com/website/sr/page/809675/Hari-Poter-doveoturiste-u-London-Filmski-turizam-osvaja-svet-dok-Srbija-kaska, accessed 10.06.2015.). Only Serbian Movie Association (Film in Serbia) is working on branding Pancevo as a cinema city at this moment (http://www.filminserbia.com, accessed 10.06.2015.).

City of Pancevo and a large number of participants in culture recognized capacities and potentials for cultural development in the city. They are continuously working on improving cultural policy which is manifested through numerous activities and cultural contents, getting them more and more diverse. Results of the research in 2013. stimulated cultural workers so now they are showing interest in networking with the civil sector too, they consider cultural needs of the audience, perceive problems and are currently working on connecting with educational institutions according to plan.

\section{References}

Lazarevic, A. (ed.) 2010, Cultural policies of Serbian cities. Cultural resources of the cities. Belgrade: the Center for Study in Cultural Development

Lazarevic, A. (ed.) 2011, Cultural resources of Serbian counties. Belgrade: the Center for Study in Cultural Development

Mikic, H. 2014, Creative industries Serbia. Belgrade: Foundation Creative Economy Group Mrdja, S. 2011a, Cultural life and needs of high school students in Serbia. Belgrade: the Center for Study in Cultural Development

Mrdja, S. 2011b, Cultural life and needs of university students in Serbia. Belgrade: the Center for Study in Cultural Development

Mrdja, S., Subasic, B., Opacic, B. 2014, The results of the sociological research in culture and action plan of City of Pancevo for 2014 and 2015. City of Pancevo

Mrdja, S., Subasic, B., Opacic, B. 2014, Report, main results of sociological research in culture and action plan of City of Pancevo for 2014 and 2015. (non-published report)

Subasic, B., Milankov, M., Graf,M. 2012, Cultural treasure of the South and East Serbia region. Belgrade: the Center for Study in Cultural Development

Subasic, B., Opacic, B. 2013, Values and cultural activism of graduate students in Serbia: the Center for Study in Cultural Development

\section{Internet sources:}

http://www.wwcd.org/policy/Stockholm.html

http://zaprokul.org.rs/wp-content/uploads/2015/01/Sabac analiza.pdf

http://www.pancevo.com/poseti-pancevo 
http://www.pancevofilmfestival.com

http://www.ekapija.com/website/sr/page/809675/Hari-Poter-doveo-turiste-u-

London-Filmski-turizam-osvaja-svet-dok-Srbija-kaska

http://www.filminserbia.com

\section{Documents:}

The Law on Government. Development of Education Strategy in Serbia up to 2020 Official

Gazette of Republic of Serbia 55/05, 71/05 correction, 101/07, 65/08, 16/11, 68/12

- US and $72 / 12$

The Law on Culture, Official Gazette of Republic of Serbia 72/2009

The Law on Education, Official Gazette of Republic of Serbia 72/2009,52/2011 and $55 / 2013$ 